\title{
Update on the Growth and Yield of the Rockland Red Pine Plantation
}

\author{
by
}

\author{
F.W. von Althen ${ }^{1}$ and W.M. Stiell ${ }^{2}$
}

In the autumn of 1981 the Rockland red pine (Pinus resinosa Ait.) plantation plots were remeasured for the ninth time. Since this stand is the oldest managed red pine plantation in Ontario for which detailed growth records have been kept, the results obtained provide a unique comparison of long-term yields from managed and unmanaged portions of the same plantation.

Planted in 1914, the stand has been intensively managed for the last 43 years. Two permanent sample plots were established in 1938, one of which was thinned in 1938, 1951, 1961 and 1971 while the other was left undisturbed. Diameter

${ }^{1}$ Research Scientist, Department of the Environment, Canadian Forestry Service, Great Lakes Forest Research Centre, Sault Ste. Marie, Ontario.

${ }^{2}$ Research Scientist, Department of the Environment, Canadian Forestry Service, Petawawa National Forestry Institute, Chalk River, Ontario. and height of trees in both plots were measured in 1938, 1943, $1951,1956,1961,1966,1971,1976$ and 1981. Seven publications have described stand development to 1976 (Sisam 1939, Mulloy 1943, 1946, Stiell 1953, 1957, von Althen and Stiell 1965, von Althen, Stiell and Foster 1978).

In 1981, the height and diameter of the tree of average basal area were $89 \mathrm{ft}$ and 12.3 in., respectively, in the thinned stand and $88 \mathrm{ft}$ and $9.4 \mathrm{in}$. in the control. The average height of dominants and co-dominants combined was 93 and $92 \mathrm{ft}$, respectively, in the thinned stand and the control. The tallest tree was $96 \mathrm{ft}$ high and was located in the control.

Growth data for the thinned and unthinned plots are given in Table 1. In the control plot a maximum basal area of 231 $\mathrm{ft}^{2}$ was reached at 52 years from planting. For the last 15 years natural mortality in this plot exceeded growth for a net

\begin{tabular}{|c|c|c|c|c|c|c|c|c|c|c|c|}
\hline \multirow[b]{2}{*}{ Age } & \multirow[b]{2}{*}{ Year } & \multicolumn{2}{|c|}{ Number of trees } & \multicolumn{2}{|c|}{$\begin{array}{c}\text { Basal area } \\
\left(\mathrm{ft}^{2}\right)\end{array}$} & \multicolumn{2}{|c|}{$\begin{array}{c}\text { Total vol } \\
\left(\mathrm{ft}^{3}\right)\end{array}$} & \multicolumn{2}{|c|}{$\begin{array}{l}\text { Merch. vol } \\
\left(\mathrm{ft}^{3}\right)^{a}\end{array}$} & \multicolumn{2}{|c|}{$\begin{array}{l}\text { Merch. vol } \\
(\mathrm{fbm})^{\mathrm{b}}\end{array}$} \\
\hline & & Thinned & Control & Thinned & Control & Thinned & Control & Thinned & Control & Thinned & Control \\
\hline 24 & $\begin{array}{l}\frac{1938}{\mathrm{BT}^{\mathrm{c}}} \\
\mathrm{T}^{\mathrm{a}} \\
\mathrm{AT}^{e}\end{array}$ & $\begin{array}{l}912 \\
\frac{322}{590}\end{array}$ & $\begin{array}{l}976 \\
\frac{-}{976}\end{array}$ & $\begin{array}{r}193 \\
53 \\
140\end{array}$ & $\frac{201}{\frac{-}{201}}$ & $\begin{array}{l}3681 \\
1000 \\
2681\end{array}$ & $\begin{array}{l}3820 \\
\frac{-}{3820}\end{array}$ & $\begin{array}{l}2349 \\
\frac{488}{1861}\end{array}$ & $\begin{array}{l}2364 \\
\frac{-}{2364}\end{array}$ & $\begin{array}{r}1488 \\
\frac{90}{1398}\end{array}$ & $\begin{array}{l}2096 \\
\frac{-}{2096}\end{array}$ \\
\hline 29 & $\begin{array}{l}\frac{1943}{\mathrm{BT}} \\
\mathrm{GPI}^{f} \\
\mathrm{~m}^{g}\end{array}$ & $\begin{array}{r}582 \\
-8\end{array}$ & $\frac{884}{92}$ & $\begin{array}{r}157 \\
18 \\
1\end{array}$ & $\begin{array}{r}208 \\
20 \\
13\end{array}$ & $\begin{array}{r}3408 \\
752 \\
25\end{array}$ & $\begin{array}{r}4475 \\
896 \\
241\end{array}$ & $\begin{array}{r}2547 \\
703 \\
17\end{array}$ & $\begin{array}{r}3032 \\
676 \\
8\end{array}$ & $\begin{array}{r}5353 \\
3955 \\
0\end{array}$ & $\begin{array}{r}4366 \\
2270 \\
0\end{array}$ \\
\hline 37 & $\begin{array}{l}\frac{1951}{B T} \\
\mathrm{~T} \\
\mathrm{AT} \\
\mathrm{GPI} \\
\mathrm{M}\end{array}$ & $\begin{array}{c}566 \\
\frac{162}{404} \\
- \\
16\end{array}$ & $\begin{array}{c}\frac{802}{-} \\
\frac{-}{802} \\
\frac{-}{82}\end{array}$ & $\begin{array}{r}184 \\
\frac{40}{144} \\
30 \\
3\end{array}$ & $\begin{array}{r}212 \\
\frac{-}{212} \\
17 \\
13\end{array}$ & $\begin{array}{r}4725 \\
1001 \\
3724 \\
1385 \\
68\end{array}$ & $\begin{array}{r}5366 \\
\frac{-}{5366} \\
1179 \\
288\end{array}$ & $\begin{array}{r}3825 \\
\quad 719 \\
3106 \\
1303 \\
25\end{array}$ & $\begin{array}{r}4059 \\
\frac{-}{4059} \\
1178 \\
151\end{array}$ & $\begin{array}{r}13406 \\
1422 \\
11984 \\
8067 \\
25\end{array}$ & $\begin{array}{r}9018 \\
-\quad \\
9018 \\
4652 \\
0\end{array}$ \\
\hline 42 & $\begin{array}{l}\frac{1956}{B T} \\
\text { GPI } \\
M\end{array}$ & $\frac{404}{-}$ & $\frac{730}{72}$ & $\begin{array}{r}161 \\
17 \\
0\end{array}$ & $\begin{array}{r}216 \\
15 \\
11\end{array}$ & $\begin{array}{r}4609 \\
885 \\
0\end{array}$ & $\begin{array}{r}5949 \\
849 \\
266\end{array}$ & $\begin{array}{r}3925 \\
819 \\
0\end{array}$ & $\begin{array}{r}4702 \\
827 \\
184\end{array}$ & $\begin{array}{r}17963 \\
5979 \\
0\end{array}$ & $\begin{array}{r}13790 \\
4772 \\
0\end{array}$ \\
\hline 47 & $\begin{array}{l}\frac{1961}{\mathrm{BT}} \\
\mathrm{T} \\
\mathrm{AT} \\
\mathrm{GPI} \\
\mathrm{M}\end{array}$ & $\begin{array}{r}400 \\
82 \\
318 \\
- \\
4\end{array}$ & $\begin{array}{c}\frac{678}{\frac{-}{678}} \\
\frac{-}{52}\end{array}$ & $\begin{array}{r}179 \\
32 \\
147 \\
19 \\
1\end{array}$ & $\begin{array}{r}223 \\
\frac{-}{223} \\
16 \\
9\end{array}$ & $\begin{array}{r}5476 \\
968 \\
4508 \\
891 \\
24\end{array}$ & $\begin{array}{r}6753 \\
\frac{-}{6753} \\
1047 \\
243\end{array}$ & $\begin{array}{r}4704 \\
816 \\
3888 \\
798 \\
19\end{array}$ & $\begin{array}{r}5470 \\
- \\
5470 \\
937 \\
169\end{array}$ & $\begin{array}{r}23309 \\
3575 \\
19374 \\
5346 \\
0\end{array}$ & $\begin{array}{r}20250 \\
\frac{-}{20250} \\
6460 \\
0\end{array}$ \\
\hline 52 & $\begin{array}{l}\frac{1966}{B T} \\
\text { GPI } \\
M\end{array}$ & $\begin{array}{r}318 \\
- \\
0\end{array}$ & $\frac{630}{-}$ & $\begin{array}{r}165 \\
18 \\
0\end{array}$ & $\begin{array}{r}231 \\
17 \\
9\end{array}$ & $\begin{array}{r}5457 \\
949 \\
0\end{array}$ & $\begin{array}{r}7380 \\
895 \\
268\end{array}$ & $\begin{array}{r}4770 \\
882 \\
0\end{array}$ & $\begin{array}{r}6173 \\
899 \\
196\end{array}$ & $\begin{array}{r}25711 \\
5977 \\
0\end{array}$ & $\begin{array}{r}26378 \\
6220 \\
92\end{array}$ \\
\hline 57 & $\begin{array}{l}\frac{1971}{B T} \\
T \\
\text { AT } \\
\text { GPI } \\
M\end{array}$ & $\begin{array}{r}314 \\
154 \\
160 \\
- \\
4\end{array}$ & $\begin{array}{c}\frac{550}{550} \\
\frac{-}{80}\end{array}$ & $\begin{array}{r}180 \\
73 \\
107 \\
16 \\
1\end{array}$ & $\begin{array}{r}224 \\
\frac{-}{224} \\
11 \\
18\end{array}$ & $\begin{array}{r}6211 \\
2468 \\
3743 \\
791 \\
37\end{array}$ & $\begin{array}{r}7625 \\
\frac{-}{7625} \\
783 \\
538\end{array}$ & $\begin{array}{r}5405 \\
2113 \\
3292 \\
665 \\
30\end{array}$ & $\begin{array}{r}6557 \\
\frac{-}{6557} \\
795 \\
411\end{array}$ & $\begin{array}{r}30812 \\
11366 \\
19446 \\
5217 \\
116\end{array}$ & $\begin{array}{r}31228 \\
\frac{-}{31228} \\
5094 \\
244\end{array}$ \\
\hline 62 & $\begin{array}{l}\frac{1976}{B T} \\
\text { GPI } \\
M \\
1981\end{array}$ & $\frac{158}{-}$ & $\frac{512}{38}$ & $\begin{array}{r}117 \\
11 \\
1\end{array}$ & $\begin{array}{r}227 \\
13 \\
10\end{array}$ & $\begin{array}{r}4291 \\
590 \\
42\end{array}$ & $\begin{array}{r}8175 \\
858 \\
308\end{array}$ & $\begin{array}{r}3839 \\
583 \\
36\end{array}$ & $\begin{array}{r}6942 \\
625 \\
240\end{array}$ & $\begin{array}{r}22612 \\
3378 \\
212\end{array}$ & $\begin{array}{r}35736 \\
4850 \\
342\end{array}$ \\
\hline & $\begin{array}{l}\text { BT } \\
\text { GPI } \\
M\end{array}$ & $\frac{158^{h}}{-}$ & $\frac{460^{i}}{52}$ & $\begin{array}{r}130 \\
13 \\
0\end{array}$ & $\begin{array}{r}219 \\
6 \\
14\end{array}$ & $\begin{array}{r}4844 \\
553 \\
0\end{array}$ & $\begin{array}{r}8190 \\
496 \\
481\end{array}$ & $\begin{array}{r}4398 \\
559 \\
0\end{array}$ & $\begin{array}{r}7137 \\
563 \\
368\end{array}$ & $\begin{array}{r}26382 \\
3770 \\
0\end{array}$ & $\begin{array}{r}38892 \\
3890 \\
734\end{array}$ \\
\hline
\end{tabular}

${ }^{a}$ Trees 6 in. DBH and larger, ${ }^{b}$ Trees 8 in. DBH and larger. ${ }^{c} \mathrm{BT}-$ before thinning, ${ }^{d} \mathrm{~T}-$ thinning. ${ }^{e} \mathrm{AT}-$ after thinning, ${ }^{f} \mathrm{GPI}-\mathrm{gross}$ periodic increment, $g_{\mathrm{M}}-\mathrm{mortality}{ }{ }$ includes 2 trees cut by vandals, includes 10 trees cut by vandals. 
loss of $12 \mathrm{ft}^{2}$, and during the last 5 years natural mortality nearly equalled total volume growth. Since this mortality occurred in only the smallest trees, the 5-year growth in merchantable cubic and board foot volume increased by a net $195 \mathrm{ft}^{3}$ and $3156 \mathrm{fbm}$, respectively. At the same time the net increase in the thinned plot was $559 \mathrm{ft}^{3}$ and $3770 \mathrm{fbm}$.

The economic analysis of the 1971 data showed that the financial maturity at $4 \%$ and $6 \%$ was highest in year 47 in both thinned and control stands. However, physical growth has continued and the thinned stand and control have produced an additional net merchantable board foot volume of 18374 and $18642 \mathrm{fbm}$, respectively, during the last 20 years. Therefore, value is still increasing, although height growth has recently fallen off markedly in both plots.

Stand conditions in the control are poor because most small trees have made little or no diameter growth, crowns are short and stems show excessive sweep or lean. Mortality continues at more than $2 \%$ per year and the risk of mass collapse from a fall of wet snow seems high. Nevertheless, the merchantable volume of this untreated plantation exceeds by $40 \%$ that given for Site Class I of natural red pine stands of the same age (Plonski 1960). This is an excellent example of the superior productivity made possible in plantations by uniform spacing and high stocking alone.

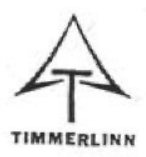

Tel.: (819) 326-3559

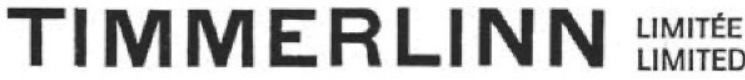

PROFESSIONAL AND TECHNICAL SERVICES IN FORESTRY AND ENVIRONMENTAL SCIENCES

R.R. No. 2, STE. AGATHE DES MONTS, QUE. J8C $2 Z 8$

\section{Woodlot Service (1978) Ltd.}

"All Matters Pertaining to Forestry"

GORDON B. YOUNG, B.Sc.F., M.F. Registered Professional Forester
320 Maple Street

Fredericton, N.B.
Bus.: $506-472-3396$

Home: 506 - 472-7721

\section{References}

Mulloy, G.A. 1943. Growth of red pine plantations under management. Can. Dep. Mines Resour., Dom. For. Serv., Silvic. Leafl. No. 17.

Mulloy, G.A. 1946. Thinning red pine, Rockland, Ontario (1943). Can. Dep. Mines Resour., Dom. For. Serv., Silvic. Res. Note No. 79.

Plonski, W.L. 1960. Normal yield tables for black spruce, jack pine, aspen, white birch, tolerant hardwoods, white pine and red pine. Ont. Dep. Lands For. Silvic. Ser. No. 2, 39 p.

Sisam, J.W.B. 1939. Thinning and pruning experiment, red pine plantation, Rockland, Ontario. Can. Dep. Mines Resour., Dom, For. Serv., Silvic. Res. Note No. 57.

Stiell, W.M. 1953. Thinning and growth in a red pine plantation. Can. Dep. Resour. Devel., For. Br., Div. For. Res., Silvic. Leafl. No. 75.

Stiell, W.M. 1957. The Rockland red pine plantation. Timber Can. April 1957.

von Althen, F.W. and Stiell, W.M. 1965. Twenty-three years of management in the Rockland red pine plantation. Dep. For., Ottawa, Ont. Publ. No. 1123.

von Althen, F.W., Stiell, W.M. and Foster, R.B. 1978. Effects of four thinnings on the growth, yield and financial returns of a 62-year-old red pine plantation. For. Chron. 54(5): 253-260.

\section{TOM GILL MEMORIAL PRIZE ESSAY COMPETITION 1983}

PRIZE: The Association's newly struck TOM GILL MEDAL and BOOKS TO THE VALUE OF $£ 40-00$.

The writer could use either of the following titles:-

1) How to make small scale tree growing profitable?

2) A new minor forest product with prospects for industrial application.

Rules of Entry

THE COMPETITION IS OPEN TO ANYONE MEMBERS or NON-MEMBERS of the Association.

Essays should not exceed $\mathbf{3 0 0 0}$ words and generally should follow the INSTRUCTIONS TO CONTRIBUTORS given on the inside back cover of the Commonwealth Forestry Review -

THERE SHOULD ALSO BE A SHORT SUMMARY

Entries (Three (3) copies please) should reach the Editor at the above address EARLY in 1983 BUT IN ANY CASE NOT LATER THAN 28th February 1983.

Winner: The WINNING ESSAY will be announced at the ANNUAL GENERAL MEETING - due to be held on 4th May 1983.

The Editor, at his discretion, may publish the winning essay or other essays submitted. whole or in part.

Previous Winners - since the commencement of the TOM GILL award are:-

O.O. Olawoye: Dr. J. Evans; P.L. Mitchell: Dr. A.I. Fraser; A.C. Frith; J. Ogilvie; J. Stewart: R.L. Chowdhary and S. Bonvoison.

The Entries are judged by the Editorial Committee of the Commonwealth Forestry Association. 